\title{
Respon Berbagai Sumber Bahan Stek terhadap Kemampuan Berakar Stek Alstonia scholaris (L) R. Br. sebagai Upaya Penyediaan Bibit untuk Lahan Terdegradasi
}

\section{Respons of The Material Cutting Retrieval on Rooting Ability of Alstonia scholaris (L) R. Br. Cuttings in an Effort Provision of Seeds for Degraded Lands}

\author{
Kiki Ayunda Putri*), Suwirmen, Zozy Aneloi Noli
}

Laboratorium Fisiologi Tumbuhan, Jurusan Biologi, FMIPA Universitas Andalas, Kampus UNAND Limau Manis Padang, 25163

${ }^{*}$ Koresponden :kikiayunda10@gmail.com

\begin{abstract}
The research about the respon of the material cuttings retrieval on rooting ability of Alstonia scholaris (L.) R. Br. Cuttings in an effort provision of seeds for Degraded lands , conducted from October until December 2015 at Physiology Plant Laboratorium of Biology Department, Mathematics and Natural Science Faculty of Andalas University, Padang. The aim of this research to found the best material cuttings on A. scholaris. This research used Completely Randomized Design (CRD) method. The treatments were the basal (A), the middle (B), and the apical $(\mathrm{C})$. The results showed that the apical was the best material cuttings, with a average number of roots (3.967), and the average of root dry weights (0.832)g. The conclusion of this research is the that material cuttings of apical is the bst one for Pulai cutting.
\end{abstract}

Keywords: material cutting, rooting ability, Alstonia scholaris

\section{Pendahuluan}

Pulai (Alstonia scholaris (L.) R. Br ) merupakan salah satu jenis indigenous species yang mampu tumbuh cepat (fast growing) dan memiliki nilai ekonomis yang tinggi (Mahfudz et al, 2013). Pulai mampu tumbuh baik pada lahan kritis dan lahan marginal sehingga dapat digunakan sebagai tanaman konservasi (Indonesian Forest Seed Project, 2001). Menurut hasil penelitian yang telah dilakukan oleh Alifah (2014), tanaman Pulai memperlihatkan pertumbuhan paling baik pada media lahan bekas tambang PT. semen padang tanpa inokulasi endomikoriza. Penelitian lain mengatakan tanaman Pulai juga berpotensi ditanam di lahan bekas tambang batu bara (Waluyo dan Ulfa, 2006).

Dari beberapa penelitian di atas, tanaman Pulai sangat berpeluang dikembangkan untuk reklamasi lahan kritis, namun pada saat ini pengadaan bibit tanaman dalam jumlah cukup secara berkesinambungan baik dari materi generatif atau vegetatif masih belum maksimal dilakukan. Karena saat ini pengadaan bibit dari materi generatif masih menghadapi kendala karena benih Pulai bersifat rekalsitran sehingga viabilitasnya relatif cepat mengalami kemunduran (Mashudi dan Leksono, 2004).

Terkait dengan hal tersebut maka pembibitan secara vegetatif dapat digunakan sebagai alternatif. Salah satu teknik perbanyakan vegetatif yang secara teknis cukup mudah dan sederhana serta tidak membutuhkan biaya produksi yang besar adalah stek. Teknik perbanyakan vegetatif dengan stek adalah metode perbanyakan tanaman dengan menggunakan bagian tanaman yang dipisahkan dari induknya dimana jika ditanam pada kondisi yang menguntungkan untuk beregenerasi akan berkembang menjadi tanaman yang sempurna (Juhardi, 1995). 
Berdasarkan hasil penelitian persen jadi stek pucuk Pulai dengan media pasir dan kompos $(1: 1)+$ rootone $\mathrm{F}$ dosis $40 \%$ relatif tinggi yaitu sebesar 88,69\% Mahfudz et al, (2013). Kemudian hasil penelitian yang lain menyatakan bahwa stek batang tanaman Pulai berumur 1 tahun di persemaian menunjukkan keberhasilan yang tinggi, yaitu berkisar antara 80,34 - 98,99\% (Mashudi et al, 2003). Dengan kata lain pembibitan secara vegetatif memiliki peluang besar dikembangkan untuk memperoleh bibit tanaman Pulai dalam jumlah cukup secara berkesinambungan sehingga dapat menunjang program reklamasi lahan kritis.

Banyak faktor yang mempengaruhi keberhasilan stek, salah satunya sumber bahan stek yang berbeda. Sumber bahan stek yang berbeda mengakibatkan adanya variasi dalam kemampuan berakar. Sumber bahan stek pada tanaman Arbutus andrachne dari bahan basal yang diperlakukan dengan hormon IBA memiliki kemampuan berakar lebih baik dibandingkan dengan stek yang berasal dari bagian apikal (Agbo dan Obi, 2007). Hal ini dikarenakan oleh kandungan nutrisi yang terdapat pada bahan stek terutama karbohidrat, protein, lipid, nitrogen, enzim, hormon dan rooting cofactor (Hartmann dan Kester, 1990). Seperti hasil penelitian Amri et al, (2009) tentang pengaruh sumber bahan stek pada kemampuan perakaran stek batang tanaman Dalbergia melanoxylon, dimana hasilnya bahan stek dari bagian basal memiliki perakaran yang lebih baik dari pada bahan stek yang berasal dari bagian tengah dan bagian apikal (Zalesn et al, 2003).

Belum diperoleh informasi mengenai potensi stek pucuk tanaman Pulai dengan berbagai sumber bahan stek. Oleh karena itu perlu dilakukan penelitian mengenai respon berbagai sumber bahan stek terhadap kemampuan perakaran pada stek tanaman Pulai untuk penyediaan bibit tanaman dalam jumlah cukup secara berkesinambungan sehingga dapat menunjang program reklamasi pada lahan kritis.

\section{Metode Penelitian}

Penelitian ini dilaksanakan pada bulan oktober sampai Desember 2015. Jorong Koto Tinggi Kenagarian Lubuk Alai kecamatan Kapur 9 Kabupaten 50 Kota dan Laboratorium Fisiologi Tumbuhan Jurusan Biologi, Fakultas Matematika dan Ilmu Pengetahuan Alam, Universitas Andalas, Padang. Penelitian ini menggunakan metode eksperimen yang disusun dalam Rancangan Acak Lengkap (RAL), perlakuan terdiri atas tiga bagian sumber bahan stek tanaman Pulai yaitu:

$\begin{array}{ll}\text { A } & \text { : Bahan stek bagian pangkal } \\ \text { B } & \text { : Bahan stek bagian tengah } \\ \text { C } & \text { : Bahan stek bagian ujung }\end{array}$

Alat-alat yang digunakan pada penelitian ini adalah gunting pangkas untuk memotong bahan stek, ember plastik digunakan untuk merendam stek, polybag untuk tempat tumbuh, media tumbuh stek, termometer untuk mengukur suhu dalam persemaian, mistar untuk mengukur panjang akar stek, timbangan analitik untuk menimbang hormon dan akar yang sudah di oven, plastik sungkup, ember plastik, kertas label, bambu, spayer, kamera dan alat tulis. Sedangkan bahan yang digunakan pada penelitian ini adalah trubusan Pulai, media pasir dan ekstrak Sargassum crassifolium $50 \%$ sebagai bahan penginduksi akar.

Pada penelitian ini diamati persentase berakar, jumlah akar, panjang akar, berat basah akar dan berat kering akar.

- Persentase berakar

- Persentase berakar dapat dihitung pada akhir penelitian dengan rumus:

Wo stek berakar $=\frac{\sum \text { stek yang berakar }}{\sum \text { semua stek }} \times 100 \%$

- Jumlah akar dan panjang akar

Jumlah akar dan panjang akar ditentukan dengan menghitung banyaknya akar primordia yang tumbuh pada akhir penelitian.

- Berat basah akar dan berat kering akar dihitung dari berat akar setelah pengamatan dilakukan. Berat kering akar dihitung dari 
berat setelah dioven di suhu $105^{\circ} \mathrm{C}$ selama dua hari.

Data hasil pengamatan dan pengukuran dianalisis menurut Rancangan Acak Lengkap. Untuk mengetahui perlakuan yang berpengaruh nyata dilakukan sidik ragam analisis varians (ANOVA) prosedur yang digunakan untuk menguji pengaruh signifikan perawatan, diikuti oleh Duncan New Multiple Range Test Duncan (DNMRT) pada taraf $5 \%$ bila pengaruh perlakuan berbeda nyata (Gomez dan Gomez, 1984).

\section{Hasil dan Pembahasan}

Jumlah Akar dan panjang akar

Perlakuan sumber bahan stek memberikan pengaruh nyata terhadap jumlah akar dan tidak memberikan pengaruh yang nyata terhadap panjang akar.Data disajikan pada Tabel 1.

Tabel 1. Rata-rata jumlah akar pada stek Pulai setelah 8 minggu masa tanamdari berbagai sumber bahan stek

\begin{tabular}{lll}
\hline $\begin{array}{l}\text { Perlakuan } \\
\text { (Batang) }\end{array}$ & $\begin{array}{l}\text { Jumlah } \\
\text { akar }\end{array}$ & $\begin{array}{l}\text { Panjang } \\
\text { akar }\end{array}$ \\
\hline Pangkal & $3,314 \mathrm{~b}$ & $2,754 \mathrm{a}$ \\
Tengah & $3,465 \mathrm{~b}$ & $2,790 \mathrm{a}$ \\
Ujung & $3,967 \mathrm{a}$ & $2,576 \mathrm{a}$ \\
\hline
\end{tabular}

Keterangan : Angka yang diikuti huruf kecil yang sama pada kolom tidak berbeda nyata pada taraf DNMRT $5 \%$

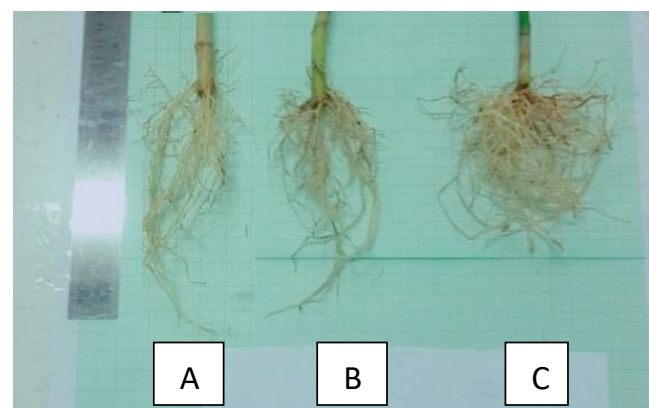

Gambar 1. Akar stek Pulai dari berbagai sumber bahan stek, (A) :bagian pangkal, (B) :bagian tengah, (C) :bagian ujung
Pada Tabel 1 dapat dilihat bahwasumber bahan stek tidak memberikan pengangaruh pada parameter panjang akar dan berpengaruh nyata terhadap jumlah akar. Nilai rata-rata jumlah akar tertinggi untuk sumber bahan stek adalah bahan stek yang berasal dari ujung yaitu 3,967. Hal ini kemungkinan disebabkan oleh aktifitas zat pengatur tumbuh yang terkandung di dalam bahan stek, karena ujung tanaman merupakan daerah meristematik yang aktif membelah. Sesuai dengan pendapat Suryaningsih (2004) bahwa kandungan auksin pada stek pucuk lebih tinggi dibandingkan dengan bagian dibawahnya karena auksin endogen suatu tanaman diproduksi dari jaringan meristem.

\section{Berat Basah Akar dan kerat kering akar}

Berdasarkan analisis statistik perlakuan sumber bahan stek berpengaruh nyata terhadap berat kering akar tapi tidak berpengaruh nyata terhadap berat basah akar.

Tabel 2. Rata rata Berat basah akar dan berat kering akar dari berbagai sumber bahan stek pada stek Pulai

\begin{tabular}{lll}
\hline Perlakuan & $\begin{array}{c}\text { Berat } \\
\text { basah akar }\end{array}$ & $\begin{array}{c}\text { Berat } \\
\text { kering akar }\end{array}$ \\
\hline Pangkal batang & $1,334 \mathrm{a}$ & $0,787 \mathrm{~b}$ \\
Tengahbatang & $1,300 \mathrm{a}$ & $0,774 \mathrm{~b}$ \\
Ujung batang & $1,379 \mathrm{a}$ & $0,832 \mathrm{a}$ \\
\hline
\end{tabular}

Keterangan: Angka yang diikuti huruf kecil yang sama pada kolom tidak berbeda nyata pada taraf DNMRT 5\%

Pada Tabel 2 dapat dilihat perlakuan sumber bahan stek tidak berpengaruh nyata terhadap berat basah akar tetapi berpengaruh nyata terhadap berat kering akar. Nilai rata-rata berat kering tertinggi pada bahan stek yang berasal dari bagian ujung yaitu 0,832 . Kemudian disusul oleh bahan stek yang berasal dari pangkal 0,787 dan tengah 0,774 . Hal ini disebakan karena bagian ujung lebih muda dan masih aktif membelah dibandingkan dengan bahan tanaman yang berasal dari tengah dan pangkal. Pada bagian ujung batang mampu untuk membentuk berat segar tunas dan 
jumlah daun yang lebih banyak. Semakin banyak jumlah daun yang membuka sempurna, maka proses fotosintesis berjalan dengan lancar.

Dalam proses fotosintesis di butuhkan banyak air, sehingga akan memicu pertumbuhan akar untuk mencari air yang baik di bagian atas tanaman akan merangsang pertumbuhan dibagian bawah sehingga volume akar membesar dan memperluas jangkauan akar untuk memperoleh makanan lebih banyak (Purwanti, 2008).

\section{Jumlah Daun Baru}

Berdasarkan analisis statistik perlakuan sumber bahan setek berpengaruh nyata terhadap berat kering akar tapi tidak berpengaruh nyata terhadap berat basah akar, dan disajikan pada Tabel 3.

Tabel 3. Rata rata jumlah daun baru dari berbagai asal bahan stek pada stek Pulai

\begin{tabular}{lc}
\hline $\begin{array}{c}\text { Sumber } \\
\text { Bahan Stek }\end{array}$ & Jumlah daun baru \\
\hline Pangkal batang & 3,469 a \\
Tengah batang & $3,447 \mathrm{a}$ \\
Ujung batang & $3,266 \mathrm{a}$ \\
\hline Keterangan: & $\begin{array}{l}\text { Angka yang diikuti huruf kecil } \\
\text { yang sama pada kolom tidak } \\
\text { berbeda nyata pada taraf DNMRT }\end{array}$
\end{tabular}

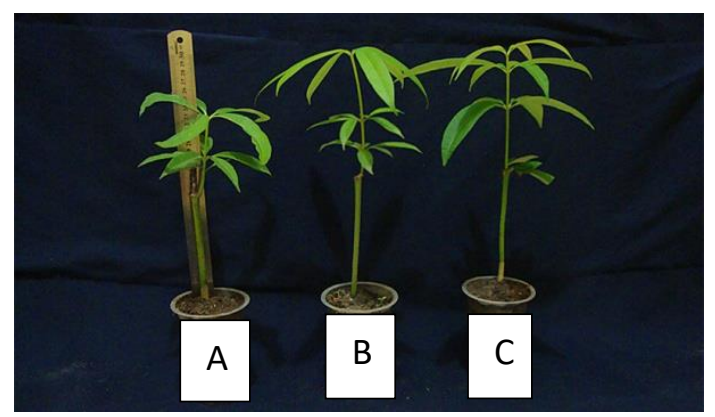

Gambar 2. Stek Pulai dari berbagai sumber bahan stek, (A):bagian pangkal, (B):bagian tengah, (C) :bagian ujung

Dapat dilihat dari tabel 3 bahwa sumber bahan stek tidak memberikan pengaruh yang nyata terhadap jumlah daun baru. Hal ini diduga karena pertumbuhan daun lebih dipengaruhi oleh faktor lingkungan. Menurut Gardner et al, (1991) bahwa jumlah dan ukuran daun dipengaruhi oleh faktor genotip dan lingkungan. Salah satu faktor lingkungan yang mempengaruhi luas daun nilam yaitu naungan. Menurut Emmyzar dan Yulius (2004) bahwa tanaman nilam respon terhadap naungan, nilam yang ditanam di bawah naungan mempunyai daun yang rimbun, sebaliknya yang ditanam pada lahan terbuka memiliki pertumbuhan daun yang kurang rimbun dengan habitus yang lebih kecil sehingga perlakuan sumber bahan setek tidak memberikan pengaruh yang berbeda nyata terhadap jumlah daun baru.

\section{Kesimpulan}

Dari penelitian ini adalah bagian ujung batang merupakan sumber bahan stek terbaik untuk pertumbuhan akar stek Pulai.

\section{Ucapan Terimakasih}

Ucapan terima kasih kepada Prof. Dr. Erizal Mukhtar, Dr.Indra Junaidi Z. dan Muhammad Nazri Janra M.Si, MA ,atas saran dan masukan pada makalah ini.

\section{DaftarPustaka}

Agbo C.U. dan Obi, I.U., 2007. Variability in propagation potentials of stem cuttings of different physiological ages of Gongronema latifolia Benth.World J Agric Sci 3(5):576581.

Alifah, N. 2014. Pertumbuhan Beberapa Jenis Bibit Pohon Hutan Yang Diinokulasikan Endomikoriza Dari НPPB Unand Pada Lahan Bekas Tambang Semen Padang. Skripsi. Universitas Andalas. Padang.

Amri E, Lyaruu, H.V.M., Nyomora, A.S., dan Kanyeka, Z.L. 2009. Vegetative Propagationof African Blackwood (Dalbergiamelanoxylon Guill. \& Perr.): Effects Of Age Of Donor Plant, IBA Treatment And Cutting 
Position On Rooting Ability Of Stem Cuttings. NewForests, 39(2): 183194.

Emmyzar dan Yulius F. 2004. Pola Budidaya Untuk Peningkatan Produktivitas dan Mutu Minyak Nilam (Pogostemon cablin Benth). http://www.balitro.go.id/index.php?.

Diakses Maret 2016

Gardner, F. P., R. B. Pearce, dan R. L. Mitchell. 1991. Fisiologi Tanaman Budidaya. terj. Universitas Indonesia Press. Jakarta.

Gomez, K.A dan A.A. Gomez, 1984. Statistical Procedures For Agricultural Research 2 nd Edition, Wiley. Pp. 100-104

Hartmann, H,T.,D.E. Kester, and F.T Davies Jr.1990. Plant Propegation,Principles And Practices. Fith Edition. Prentice Hall, Inc.Engle Wood Cliff. New Jersey.578p.

Indonesian Forest Seed Project. 2001. Informasi Singkat Benih (Alstonia scholaris (L) R.Br. Direktorat Perbenihan Tumbuhan Hutan No 2, Maret 2001. Departemen Kehutanan Indonesia.

Juhardi, D. 1995. Study Pembiakan Vegetatifstek Pucuk Shoea BL Dengan Menggunakan Zat Pengatur Tumbuh IBA Pada Campuran Tanah Dan Pasir. Skrisi Fakultas Kehutanan Institute Pertanian Bogor. Bogor

Mahfudz, M.A. Fauzi dan H.A. Adinugraha. 2013. Pengaruh Media dan Dosis Rootne-F terhadap Keberhasilan Stek Pucuk Pulai (Alstonia scholaris) (L.) R.Br.). Jurnal Pemuliaan Tanaman Hutan.Vol. 1, No.1 : 1 - 9.

Maffudz Dan M. A. Fauzi. 2006. Cara Mudah Dan Murah Memproduksi Bibit Jati Berkualitas. Rimba Indonesia (Indonesia Journal Of Forestry). 41 (1): 28-30.

Mashudi, D. Setiadi dan H,A. Adinugraha, 2003. Aplikasi Teknik Stek Batang
Pulai (Alstolnia scholaris) Dalam Pengembangan Kebun Pangkas. Jurnal Penelitian Pusat Litbang Bioteknologi dan Pemuliaan Tanaman Hutan. Vol. 1 pp : $93-100$

Mashudi dan B. Leksono. 2004. Litbang Pemuliaan Pulai untuk Menghasilkan Benih Unggul dan Perannya dalam Mendukung Program GNRHL. Prosiding Ekspose Hasil Litbang Bioteknologi dan Pemuliaan Tanaman Hutan. Pusat Penelitian dan Pengembangan Bioteknologi dan Pemuliaan Tanaman Hutan. Yogyakarta. Hlm. 53-62.

Purwanti, E. 2008. Pengaruh Dosis Pupuk Majemuk dan Konsentrasi EM-4 Terhadap Pertumbuhan Bibit Stek Tebu (Saccharum officinarum L.).Skripsi S1. Universitas Sebelas Maret. Surakarta.

Suryaningsih. 2004. Pengaruh Macam Zat Pengatur Tumbuh dan Media Tanam Terhadap Pertumbuhan Setek Lada (Piper nigrum L.).Skripsi S1. UNS Press. Surakarta.

Zuhelmi, V. 2015. Pertumbuhan Desmodium Heterophylum (Willd DC Pada Tanah Bekas Tambang Batu Kapur Di Pt. Semen Padang Dengan Pemberian Zat Pengatur Tumbuh Giberelin (GA3). Skripsi S1. Universitas Andalas. Padang

Waluyo, E. A. \& Ulfa, M. 2006. Pengaruh Inokulasi Cendawan Mikoriza Arbuskular (CMA) Terhadap Pertumbuhan Pulai Darat (Alstonia Angustiloba Miq.) Di Lahan Bekas Tambang Batubara. Seminar HasilHasil Penelitian Hutan Tanaman Balai Penelitian Kehutanan (BPK). Palembang.

Zalesny R. S., Hal R. B., Baeur E. O., Riemenchnider D.E (2003) Shoot Position affect root initiation and growth of dorman unrooted cuttings of populs.Silvae Genet 52 (8) : 273279 